\title{
Muscle Biopsy Measurement of Body Water and Intracellular Electrolytes in Children
}

\author{
J. A. GRAHAM and W. G. SCOBIE \\ From the Department of Surgery, Western Infirmary, Glasgow, and Department of Paediatric' Surgery, Oakbank \\ Hospital, Glasgow
}

\begin{abstract}
Graham, J. A., and Scobie, W. G. (1970). Archives of Disease in Childhood, 45, 473. Muscle biopsy measurement of body water and intracellular electrolytes in children. Body water and electrolytes have been measured in normal infants and children using a muscle biopsy technique. Extracellular water, sodium, and chloride contents per kilogram dry weight are high in infancy but fall to adult values by 18 months to 2 years. Intracellular water and potassium contents are initially high, but approximate to adult levels around 6 months of age. Large variations in water and electrolyte contents have been found in apparently normal children.

There is good correlation between extracellular water and sodium content, and between intracellular water and potassium content. Therefore intracellular electrolyte concentrations are similar for children of all ages.

This technique is presented as a useful method of obtaining information about fluid and electrolyte balance in children.
\end{abstract}

Body water content of infants and young children has been measured using indicator-dilution techniques (Friis-Hansen, 1957; Smull, 1958; Hanna, 1960; Cheek, 1961; Clapp, Butterfield, and O'Brien, 1962; Maclaurin, 1966). Electrolyte content has been measured using these techniques (Forbes, 1952; Cheek, 1954; Corsa et al., 1956). Indicatordilution studies have some limitations and are laborious to perform.

Measurement of body water and electrolyte contents by means of skeletal muscle biopsy is a well-recognized technique in adults (Bergström, 1962; Graham, Lamb, and Linton, 1967; Flear, Florence, and Williams, 1968). It is simple, quick, and easy, and gives results at least as accurate as indicator-dilution techniques. Nichols, Hazlewood, and Barnes (1968) have used percutaneous needle biopsy to study some aspects of skeletal muscle biochemistry in children. The following presentation gives the findings of muscle biopsy studies carried out on a series of normal children.

\section{Subjects and Methods}

Thirty-three normal children have been studied ranging in age from 2 weeks to 9 years. They were all

Received 10 November 1969. admitted to hospital for elective surgical procedures. None had clinical evidence of fluid and electrolyte imbalance or any disease process likely to cause this. The details of the procedure were explained to all the parents and their consent was freely given.

A small piece of skeletal muscle (100-150 mg.) was taken from a muscle exposed by the surgical incision (rectus abdominis or internal oblique in all cases). This biopsy was divided into three portions, after removing any excess blood and connective tissue. Analysis of the water and electrolyte contents and partition into extraand intracellular phases was then carried out as previously described (Graham et al., 1967).

Serum electrolytes were measured using standard laboratory techniques.

\section{Results}

Analysis of the results of the biopsy specimens into age-groups shows a large scatter of values in the first two years of life. The mean values for all patients over 2 years of age have an acceptable standard deviation, and Table I shows that they do not differ significantly from the mean values for normal adults found by Graham et al. (1967).

Individual results for all patients below 2 years of age are shown in Table II. Serum electrolytes are not shown, but were within normal limits except for 
TABLE I

Comparison of Mean Muscle Water and Electrolytes for Subjects more than 2 years old, with mean values for Normal Adults (data from Graham et al., 1967)

\begin{tabular}{|c|c|c|c|c|c|c|c|c|c|c|}
\hline \multirow[t]{2}{*}{ Group } & \multirow[t]{2}{*}{ Value } & \multicolumn{3}{|c|}{$\begin{array}{l}\text { Muscle Water } \\
\text { (ml./kg. dry wt.) }\end{array}$} & \multicolumn{3}{|c|}{$\begin{array}{l}\text { Total Muscle Electrolytes } \\
\text { (mEq/kg. dry wt.) }\end{array}$} & \multicolumn{3}{|c|}{$\begin{array}{l}\text { Intracellular Electrolytes } \\
(\mathrm{mEq} / 1 .)\end{array}$} \\
\hline & & Total & Extracellular & Intracellular & Sodium & Potassium & Chloride & Sodium & Potassium & Chloride \\
\hline Children & Mean & 3325 & 747 & 2579 & 154 & 424 & 88 & 20 & 165 & $4 \cdot 3$ \\
\hline $\begin{array}{l}2-9 \text { yr. } \\
(n=9)\end{array}$ & SD & 336 & 128 & 320 & 19 & 36 & 11 & 7 & 11 & $0 \cdot 2$ \\
\hline $\begin{array}{l}\text { Adults } \\
\qquad(n=40)\end{array}$ & $\begin{array}{l}\text { Mean } \\
\text { SD }\end{array}$ & $\begin{array}{r}3179 \\
189\end{array}$ & $\begin{array}{l}710 \\
211\end{array}$ & $\begin{array}{r}2471 \\
190\end{array}$ & $\begin{array}{r}148 \\
29\end{array}$ & $\begin{array}{r}414 \\
35\end{array}$ & $\begin{array}{l}84 \\
22\end{array}$ & $\begin{array}{r}19 \\
6\end{array}$ & $\begin{array}{r}167 \\
11\end{array}$ & $\begin{array}{l}4 \cdot 3 \\
0 \cdot 2\end{array}$ \\
\hline
\end{tabular}

No difference is statistically significant.

TABLE II

Individual Muscle Water and Electrolytes for Subjects up to 2 Years of Age

\begin{tabular}{|c|c|c|c|c|c|c|c|c|c|}
\hline \multirow{2}{*}{$\begin{array}{c}\text { Age } \\
\text { (mth.) }\end{array}$} & \multicolumn{3}{|c|}{$\begin{array}{l}\text { Muscle Water } \\
\text { (ml./kg. dry wt.) }\end{array}$} & \multicolumn{3}{|c|}{$\begin{array}{l}\text { Total Muscle Electrolytes } \\
\text { (mEq/kg. dry wt.) }\end{array}$} & \multicolumn{3}{|c|}{$\begin{array}{l}\text { Intracellular Electrolytes } \\
(\mathrm{mEq} / 1 .)\end{array}$} \\
\hline & Total & Extracellular & Intracellular & Sodium & Potassium & Chloride & Sodium & Potassium & Chloride \\
\hline $\begin{array}{l}0 \cdot 5 \\
0 \cdot 75 \\
1 \cdot 25 \\
1 \cdot 25 \\
1 \cdot 75 \\
1 \cdot 75 \\
3 \cdot 0 \\
5 \cdot 0 \\
5 \cdot 0 \\
7 \cdot 5 \\
7 \cdot 75 \\
7 \cdot 75 \\
8 \cdot 0 \\
8 \cdot 5 \\
10 \cdot 0 \\
10 \cdot 0 \\
12 \cdot 0 \\
15 \cdot 0 \\
16 \cdot 0 \\
18 \cdot 0 \\
20 \cdot 0 \\
21 \cdot 0 \\
24 \cdot 0 \\
24 \cdot 0\end{array}$ & $\begin{array}{l}5143 \\
4119 \\
3740 \\
3695 \\
3266 \\
3732 \\
3831 \\
3811 \\
3689 \\
3314 \\
3219 \\
4482 \\
3319 \\
3335 \\
3426 \\
3136 \\
3309 \\
3933 \\
3369 \\
3265 \\
3505 \\
3052 \\
3664 \\
3402\end{array}$ & $\begin{array}{r}1769 \\
1101 \\
1040 \\
1122 \\
1077 \\
1012 \\
839 \\
1182 \\
727 \\
789 \\
666 \\
956 \\
1148 \\
840 \\
942 \\
610 \\
881 \\
1185 \\
862 \\
927 \\
1055 \\
716 \\
1004 \\
944\end{array}$ & $\begin{array}{l}3373 \\
3017 \\
2700 \\
2573 \\
2188 \\
2720 \\
2992 \\
2629 \\
2911 \\
2524 \\
2553 \\
3526 \\
2171 \\
2495 \\
2483 \\
2536 \\
2428 \\
2747 \\
2507 \\
2337 \\
2449 \\
2336 \\
2659 \\
2458\end{array}$ & $\begin{array}{l}310 \\
233 \\
209 \\
226 \\
170 \\
205 \\
155 \\
201 \\
170 \\
152 \\
188 \\
228 \\
218 \\
186 \\
148 \\
134 \\
176 \\
211 \\
134 \\
167 \\
205 \\
156 \\
172 \\
186\end{array}$ & $\begin{array}{l}614 \\
494 \\
473 \\
466 \\
362 \\
468 \\
490 \\
448 \\
441 \\
391 \\
397 \\
564 \\
407 \\
416 \\
411 \\
447 \\
412 \\
428 \\
418 \\
459 \\
391 \\
451 \\
420 \\
460\end{array}$ & $\begin{array}{r}199 \\
129 \\
116 \\
130 \\
119 \\
128 \\
100 \\
130 \\
98 \\
96 \\
94 \\
121 \\
126 \\
96 \\
112 \\
79 \\
105 \\
133 \\
105 \\
114 \\
122 \\
86 \\
113 \\
109\end{array}$ & $\begin{array}{r}20 \\
26 \\
21 \\
27 \\
10 \\
22 \\
13 \\
16 \\
23 \\
16 \\
36 \\
27 \\
24 \\
27 \\
8 \\
19 \\
23 \\
19 \\
6 \\
16 \\
26 \\
25 \\
15 \\
19\end{array}$ & $\begin{array}{l}180 \\
162 \\
173 \\
179 \\
163 \\
170 \\
162 \\
169 \\
151 \\
153 \\
154 \\
159 \\
187 \\
166 \\
164 \\
167 \\
168 \\
154 \\
165 \\
194 \\
159 \\
191 \\
157 \\
185\end{array}$ & $\begin{array}{l}4 \cdot 3 \\
4 \cdot 4 \\
4 \cdot 3 \\
4 \cdot 4 \\
4 \cdot 3 \\
4 \cdot 3 \\
4 \cdot 3 \\
4 \cdot 2 \\
4 \cdot 5 \\
4 \cdot 5 \\
5 \cdot 1 \\
4 \cdot 6 \\
4 \cdot 3 \\
4 \cdot 3 \\
4 \cdot 5 \\
4 \cdot 6 \\
4 \cdot 5 \\
4 \cdot 3 \\
4 \cdot 5 \\
4 \cdot 6 \\
4 \cdot 4 \\
4 \cdot 4 \\
4 \cdot 2 \\
4 \cdot 3\end{array}$ \\
\hline
\end{tabular}

slight increase in the urea concentration in 7 subjects. There was no clinical evidence of abnormality in these patients and they have therefore been included as normal; possible causes for this will be discussed later. These biopsy specimen results are further analysed in Fig. 1 to 6.

Fig. 1 and 2 show, respectively, the total and extracellular water content of muscle. There is a tendency for both to decrease with age.

Fig. 3 and 4 show the total sodium and chloride content of muscle. The values are initially high but tend to fall into the adult range around 18 months to 2 years.
Fig. 5 shows the muscle intracellular water content and Fig. 6 the total potassium content. Again there is an increase in both in the youngest children, but after about 6 months both approximate closely to the normal adult range.

A highly significant correlation exists between the extracellular water and total sodium content of muscle, throughout the entire age range studied (Fig. 7). A similar correlation is found between intracellular water and total potassium content (Fig. 8). These correlations have been shown for normal adults (Graham et al., 1967), and therefore appear to hold good at all ages. Because of these 


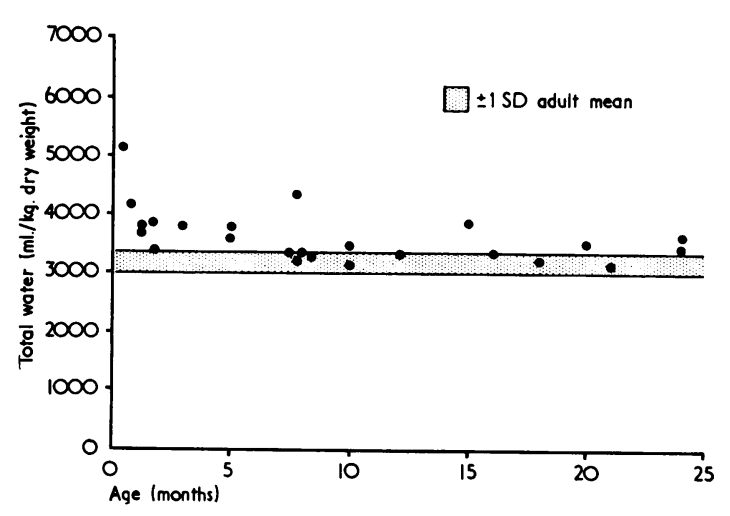

FIG. 1.-Total muscle water content of children up to 2 years of age (shown against $\pm 1 S D$ normal adult mean).

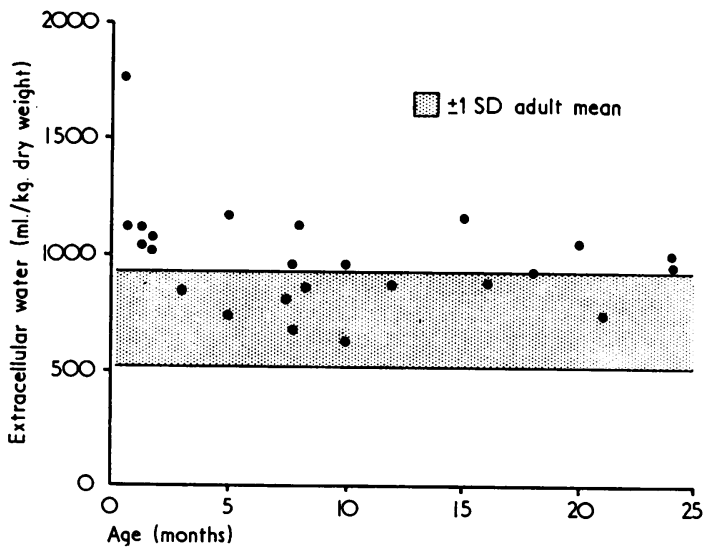

FIG. 2. Extracellular muscle water content of children up to 2 years of age (shown against $\pm 1 S D$ normal adult mean).

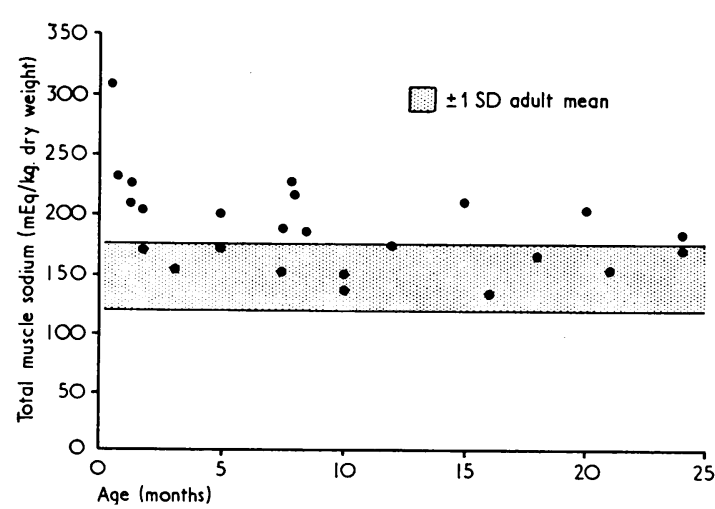

Fig. 3.-Total muscle sodium content of children up to 2 years of age (shown against $\pm 1 S D$ normal adult mean).

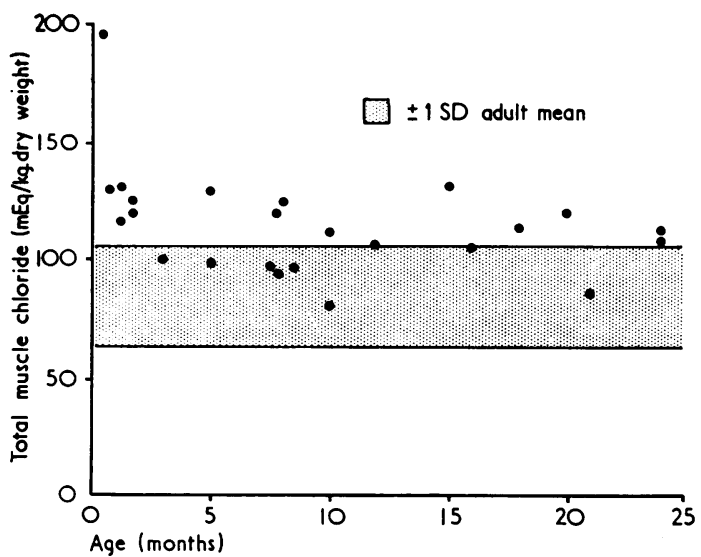

FIG. 4.-Total muscle chloride content of children up to 2 years of age (shown against $\pm 1 S D$ normal adult mean).

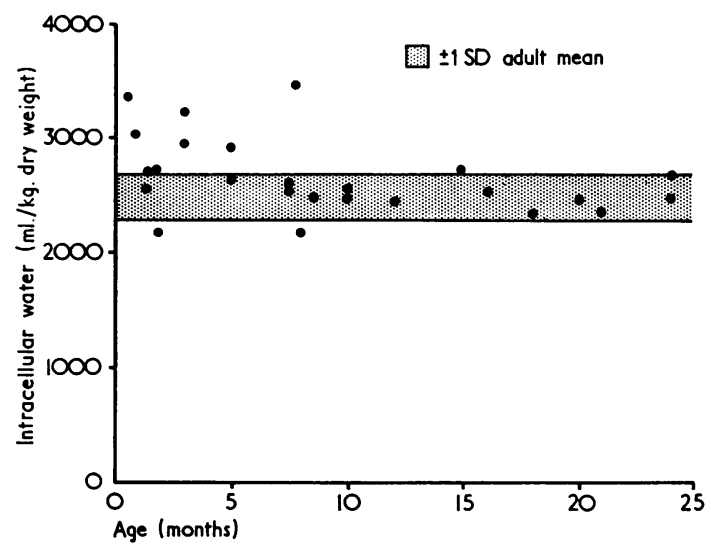

FIG. 5.-Intracellular muscle water content of children up to 2 years of age (shown against $\pm 1 S D$ normal adult mean).

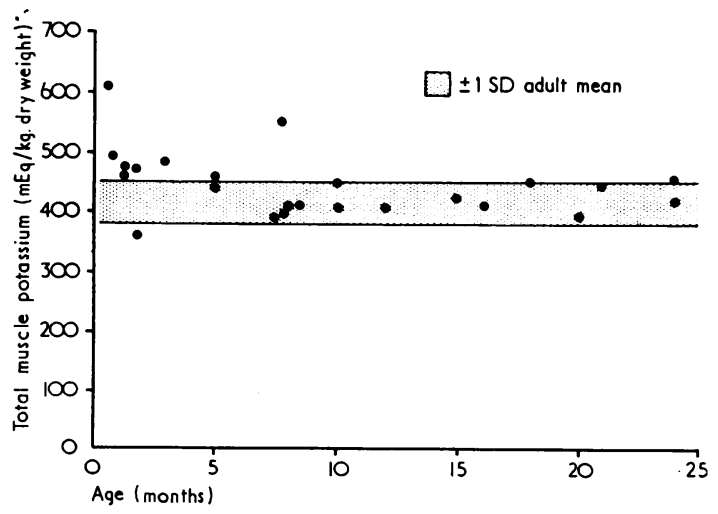

Fig. 6.-Total muscle potassium content of children up to 2 years of age (shown against $\pm 1 S D$ normal adult mean). 


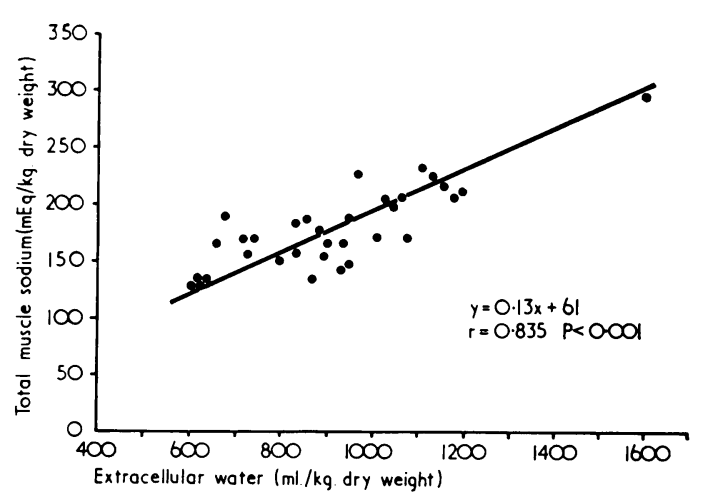

FIG. 7.-Correlation between sodium content and extracellular water in muscle.

close relationships, the intracellular electrolyte concentrations lie within relatively narrow limits at all ages, and the mean values for this whole series are close to that of normal adults, being: potassium $167 \pm 13 \mathrm{mEq} /$ litre cell water ( $t$ one $S D$ ); sodium $20 \pm 7 \mathrm{mEq} / \mathrm{litre}$; and chloride $4.4 \pm 0.2 \mathrm{mEq} /$ litre.

\section{Discussion}

Previously reported work on body water and electrolyte content in young children has utilized tracer-dilution methods which have distinct limitations. Incomplete equilibration or entry into compartments other than those under study, and loss of tracer from the body, can introduce error, especially under pathological conditions. Furthermore, there may be a possible radiation hazard in the administration of radioisotopes to children.

The advantage of muscle biopsy studies is that no tracer substances are given, only endogenous water and electrolytes being measured. The method is quick and simple, and the results obtained correlate well with measurements of total body content both in adults (Muldowney and Williams, 1963) and children (Nichols et al., 1969).

We have only taken specimens from children having surgical procedures, using muscles exposed by the surgical incision. This, however, raises some problems. It is difficult to find very young children who are having surgery and in whom it seems fairly certain that the body water and electrolyte contents have not been altered. Furthermore, these children may have had normal eating and drinking habits upset by admission to hospital. The high blood urea values in some of our cases were probably due to a degree of dehydration; McCance and Widdowson (1947) have shown that the blood urea rises very quickly in dehydrated

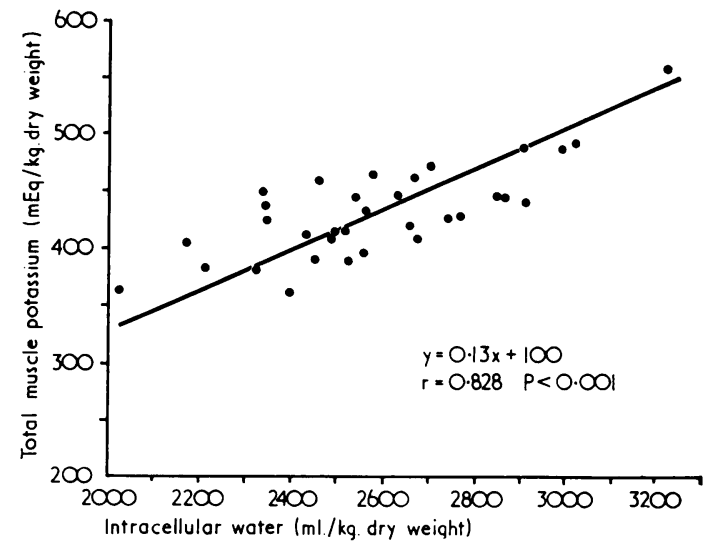

FIG. 8.-Correlation between potassium content and intracellular water in muscle.

normal infants. Part of the variability of the results for water and electrolyte content in this and other series (e.g. Friis-Hansen, 1957; Hanna, 1960) may be likewise due to alterations in intake.

Our results, expressed per unit of body weight, show a similar trend to those of previous investigators. Extracellular water and the extracellular ions, sodium and chloride, are high in the newborn and then fall slowly to reach adult values around 2 years of age. Friis-Hansen (1957) and Corsa et al. (1956) believe that there is a further slow fall in extracellular water and chloride content after this age, and that adult values are not reached till adolescence, but this is not obvious in our series.

On the other hand, high intracellular water and potassium contents in the newborn fall quickly to adult levels by about 6 months. Clapp et al. (1962) have shown a similar fall in intracellular water; Friis-Hansen (1957) believes, however, that cell water remains relatively constant throughout growth and Corsa et al. (1956) and Forbes (1952) found that the potassium content remained steady with growth. These investigators express their results per wet weight of tissue, which tends to mask minor changes in water and electrolyte content, and may explain this discrepancy.

The most interesting findings of this series are the excellent correlations between extracellular water and sodium content, and between intracellular water and potassium content. This has the effect of maintaining the intracellular electrolyte concentrations within narrow limits at all ages, the values in growing children being similar to adults. The mean intracellular potassium concentration in this series is similar to that of Corsa et al. (1956) who 
calculated a value of $165 \mathrm{mEq} /$ litre cell water. Despite changes in water and electrolyte content during growth, the cellular concentrations of electrolytes remain steady; this appears vital for the maintenance of normal electrical activity and therefore of function in the cell. This result directly contradicts the finding of Nichols et al. (1969) that the cell potassium concentration was low at birth and increased with age.

We find, in company with other investigators, that because of the large variation in water and electrolyte content in the tissues of children of the same age, it is impossible to evaluate 'normality' at any age. However, muscle biopsies are easy to take and to analyse, either at open operation or by percutaneous needle biopsy, and the results obtained will help to provide a more accurate picture of the fluid and electrolyte status of individual children.

\section{REFERENCES}

Bergström, J. (1962). Muscle electrolytes in man. Scandinavian Fournal of Clinical and Laboratory Investigation, 14, suppl. 68.

Cheek, D. B. (1954). Observations on total body chloride in children. Pediatrics, 14, 5 .

- (1961). Extracellular volume: its structure and measurement and the influence of age and disease. Fournal of Pediatrics, $58,103$.

Clapp, W. M., Butterfield, L. J., and O'Brien, D. (1962). Body water compartments in the premature infant, with special reference to the effects of the respiratory distress syndrome and of maternal diabetes and toxemia. Pediatrics, 29, 883.

Corsa, L., Jr., Gribetz, D., Cook, C. D., and Talbot, N. B. (1956). Total body exchangeable water, sodium and potassium in 'hospital normal' infants and children. Pediatrics, 17, 184.

Flear, C. T. G., Florence, I., and Williams, J. A. (1968). Water, sodium, potassium, and chloride content of skeletal muscle in fit and ill subjects. Fournal of Clinical Pathology, 21, 555.

Forbes, G. B. (1952). Chemical growth in man. Pediatrics, 8, 58.

Friis-Hansen, B. (1957). Changes in body water compartments during growth. Acta Paediatrica, 46, suppl. 110.

Graham, J. A., Lamb, J. F., and Linton, A. L. (1967). Measurement of body water and intracellular electrolytes by means of muscle biopsy. Lancet, $2,1172$.

Hanna, F. (1960). Total body water and its distribution. American Fournal of Diseases of Children, 100, 723.

McCance, R. A., and Widdowson, E. M. (1947). Blood urea in the first nine days of life. Lancet, 1, 787.

Maclaurin, J. C. (1966). Acute glomerulonephritis: a study of certain aspects. M.D. Thesis, University of Glasgow.

Muldowney, F. P., and Williams, R. T. (1963). Clinical disturbances in serum sodium and potassium in relation to alteration in total exchangeable sodium, exchangeable potassium, and total body water. American fournal of Medicine, 35, 768.

Nichols, B. L., Alleyne, G. A. O., Barnes, D. J., and Hazlewood, C. F. (1969). Relationship between muscle potassium and total body potassium in infants with malnutrition. Fournal of Pediatrics, 74, 49.

- Hazlewood, C. F., and Barnes, D. J. (1968). Percutaneous needle biopsy of quadriceps muscle: potassium analysis in normal children. Fournal of Pediatrics, 72, 840.

Smull, N. W. (1958). Total body water and bromide space determinants in premature infants. (Abstr.) American fournal of Diseases of Children, 86, 494.

Correspondence to Dr. J. A. Graham, Department of Surgery, Western Infirmary, Glasgow W.1. 